\title{
The Effects of Knowledge-Transforming Text on Elementary Students' Declarative, Procedural Knowledge, and Motivation in Environmental Learning
}

\section{Rusdhianti Wuryaningrum}

Universitas Jember, Indonesia, rusdhiyanti.fkip@unej.ac.id

\section{Singgih Bektiarso}

Universitas Jember, Indonesia, singgih.fkip@unej.ac.id

\section{Imam Suyitno}

Universitas Negeri Malang, Indonesia, imam.suyitno.fs@um.ac.id

In environmental learning, declarative and procedural knowledge is needed to to improve understanding of concepts and problem solving. The text used in KTT contains descriptions and arguments to understand declarative and procedural knowledge. This study aimed to investigate the effect of applying knowledgetransforming text (KTT) on declarative, procedural knowledge, and students' presentation skill as well as their motivation towards learning with KTT applied in environmental education material. The study applied control group design. Prior to treatment, homogeneity tests were carried out with one way ANOVA test. Furthermore, in the experimental class instructional strategy armed with KTT was in place, the result of which was then analyzed by several quantitative analyses. These analyses included (1) normality test with a non-parametric one-sample Kolmogorov-Smirnov Test; (2) Mann-Whitney U test non-parametric statistic to compares the means between unrelated groups on some continous, and (3) significance tests. The results showed that KTT posed significant effect on declarative and procedural knowledge yet it insignificantly affected student presentation skills. The significant effects of KTT learning on declarative and procedural knowledge was supported by content space, rhetorical space, and corrective elements in KTT. Quantitaive descriptive analysis was carried out by interpreting the percentage of student motivation as investigated by questionnaires on KTT learning. Students were relatively motivated towards KTT and hoped to learn to use KTT.

Keywords: knowledge-transforming text, declarative knowledge, procedural knowledge, environment education, motivation, elementary students

Citation: Wuryaningrum, R., Bektiarso, S., \& Suyitno, I. (2020). The Effects of KnowledgeTransforming Text on Elementary Students' Declarative, Procedural Knowledge, and Motivation in Environmental Learning. International Journal of Instruction, 13(1), 567-586. https://doi.org/10.29333/iji.2020.13137a 


\section{INTRODUCTION}

In the 2013 curriculum, students in Indonesia encounter various texts and tasks to understand the textual materials. In that case, language is functionally seen as a tool for understanding other subjects (Kemendikbud, 2013; Suwandi 2013). In this context, textbased learning is applied. Through text, students obtain declarative and procedural knowledge. Therefore, what needs to be provided is learning material appropriate for learning. Kul, Çelik, \& Aksu (2018) state that students need appropriate learning material to help them construct knowledge and initiate active thinking. Therefore, text as a learning material has to support knowledge building and knowledge creation (Bereiter \& Scardamalia, 2014). Text needs to completely convey a concept in the apt rhetoric and to be supported by context and made easily understood and interpreted. In this regard, text needs to be precisely produced through knowledge-transforming. In this study, the text is called knowledge-transforming text (KTT).

Bereiter \& Scardamalia (1987), as quoted by Renkema (2004: 221), describe two types of text production, namely knowledge-telling and knowledge-transforming. In knowledge-telling, the text only presents information and does not involve a variety of interesting references. In addition, it does not make any connections between sets of information to highlight important points. Instead of knowledge- transforming, the text is formed with various references and is presented by making connections between sets of information to compose interesting piece of writing.

Learning process directs students to obtain declarative knowledge through knowing or understanding, while procedural knowledge aims to enable students to carry out a series of actions. Declarative knowledge is the knowledge that we are aware of and can express certain intended meaning clearly (Baumard, 1999). Procedural knowledge means real knowledge (Sahdra \& Thagard, 2003). Jiamu (2001) posits that procedural knowledge involves basic skills and domain specific strategies; declarative knowledge and conceptual understanding of a domain. Good learning material must encourage the acquisition of both types of knowledge. Students not only understand the concept of knowledge but also explain the knowledge in procedural steps, while the rest can be practiced through demonstrations.

In the material of Pendidikan Lingkungan Hidup (PLH) or Educational Environment (EE), students in Indonesia are faced with numerous texts grounded within the 2013 curriculum. The material descriptions in textbook text are described in the following picture.

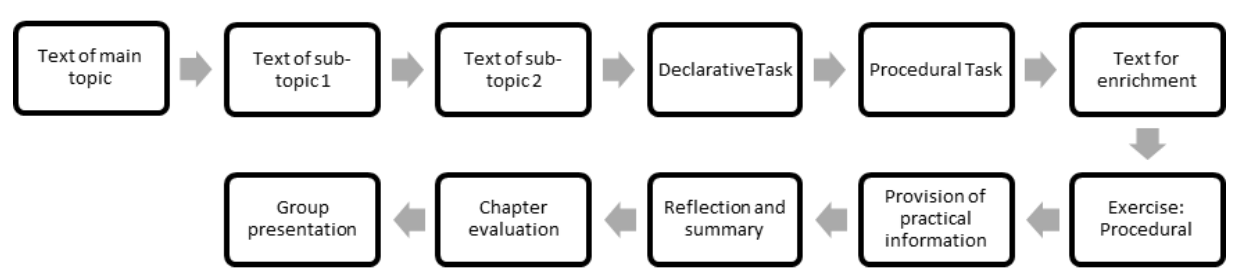

Figure 1

Material Flow per Chapter in EE Text Book in Indonesia 
The chart shows that students need to take declarative and procedural tests. Efforts to provide text are needed, particularly those which can accommodate students' needs through meaningful learning to understand the declarative and procedural knowledge. In addition, the characteristics of EE in Indonesia are scaffolding students' ability to convey ideas about their environment and grow the motivation to care about the environment.

The provision of text in transforming knowledge fashion is done by providing texts which comply with Bereiter and Scardamalia's (1987) opinions, particularly concerned with the use of such techniques as highlighting key points, restructuring various sections, drawing connections between different parts of the material, and using various contexts to support meaningful knowledge. The texts are given in specific main topic derived from sub-chapters 1 and 2. The texts used in the learning activities have been relatively knowledge-telling. Hereunder are the differences between the two types of tests.

Table 1

Texts Oriented to Knowledge-Telling Text and Knowledge-Transforming Text

\begin{tabular}{|c|c|}
\hline Knowledge-Telling & sforming \\
\hline $\begin{array}{l}\text { Family medicinal plants are functional } \\
\text { plants. The plants can be consumed as a } \\
\text { medicine, such as ginger, turmeric, betel } \\
\text { nut, and so on. Some examples of family } \\
\text { medicinal plants are turmeric, ginger, } \\
\text { betel nut, red galangal, and so on. These } \\
\text { plants can be used as traditional } \\
\text { medicine. For example, turmeric is used } \\
\text { to cure heartburn and stomachache; } \\
\text { ginger is consumed for curing cough; and } \\
\text { betel is used to treat wounds. Guava } \\
\text { leaves can also be used to cure diarrhea. } \\
\text { Family medicinal plants are very } \\
\text { beneficial for our health. You can plant } \\
\text { them in your house. If you have } \\
\text { medicinal plants at home, you can use } \\
\text { them at any time if a family member is } \\
\text { sick. These traditional medicines can also } \\
\text { be found in traditional markets and super } \\
\text { markets. }\end{array}$ & $\begin{array}{l}\text { Indonesia is famous for herbal medicines. Our } \\
\text { ancestors used herbal medicine for medication. } \\
\text { Herbs are produced from natural herbal } \\
\text { ingredients such as ginger, turmeric, reeds, } \\
\text { betel nut, white turmeric, and so on. You can } \\
\text { also use these plants as medicine. For example, } \\
\text { to make your stomach comfortable and reduce } \\
\text { heat or to obtain antibiotic you can take } 2 \\
\text { turmeric as big as an adult's thumb, peel them, } \\
\text { and mash them then boil them with two glasses } \\
\text { of water. Boil them until } 1 \text { cup of water is left } \\
\text { and add honey and lime. Turmeric herbs can be } \\
\text { consumed as medicine. It's so easy, isn't it? } \\
\text { That is medicinal plants. These medicinal } \\
\text { plants can be found at common Indonesian } \\
\text { houses. Therefore, it is also called family } \\
\text { medicinal plants. Is there any in your house? } \\
\text { If not, let's start planting the medicinal plants at } \\
\text { your home by planting the seeds as seeds. } \\
\text { Shoots will grow after } 1 \text { to } 2 \text { weeks. Be sure to } \\
\text { water them so that they continue to flourish. }\end{array}$ \\
\hline
\end{tabular}

The text knowledge-telling is produced by definition, function, example, and expansion. Thus, the text contains knowledge and efforts to convey it with information to the reader or conative function.

In transforming-knowledge texts, texts are produced with context-examples-elaborationprocedure exposure 1-definition-persuasion- procedure exposure 2 . The text is presented with conative-structural-rhetorical-persuasion facts. There is declarative and procedural knowledge presented in knowledge-transforming text. 
The purpose of text learning in EE is basically knowledge, attitude, and skills that are realized declaratively in understanding definitions, concepts, meaning of terms, and description of facts. In addition, procedurally speaking, students have to be able to explain how to solve problems in logical and appropriate stages, make products, and explain how to create the products. From the attitudinal aspect, teacher motivates students to think and act in accordance with the declarative and procedural knowledge they obtain, for example no littering, planting and caring for trees, and actively maintaining cleanliness and environmental sustainability such as holding school cleaning activities, releasing hatchlings at the beach, and planting trees around the house and school. The two types of knowledge being referred are declarative and procedural knowledge. The following is the differences and commonalities between the two.

Table 2

The Construction of Procedural and Declarative Knowledge (Developed from Marzano's model, 2012)

\begin{tabular}{ll}
\hline Declarative & Procedural \\
$\begin{array}{l}\text { The learner } \text { knows or understands a concept } \\
\text { meaning of a term }\end{array}$ & $\begin{array}{l}\text { The learner } \text { is able to actualize a concept } \\
\text { Explaining a procedure through a series of steps. }\end{array}$ \\
\hline $\begin{array}{l}\text { Information 2: facts, concepts, and } \\
\text { generalizations- }- \text { within content } \\
\text { knowledge }\end{array}$ & $\begin{array}{l}\text { The case deals with even complex processes like } \\
\text { writing, reading a bar graph, and setting up an } \\
\text { experiment. Although the sequence is not always } \\
\text { linear, there are steps which need to be performed } \\
\text { in the skills and processes }\end{array}$ \\
\hline
\end{tabular}

This research provides an overview of the impact of interdisciplinary learning. The KTT as part of a text-based learning method, on language learning, has an impact on environmental learning. The novelty of this research is concerned with the effect of learning material produced in knowledge-transforming manner towards students' declarative and procedural knowledge, as well as their ability to present their ideas. During this time, the text as learning material produced by knowledge-telling. Information is conveyed without considering rhetorical space, but employing storytelling strategies.

This study looked at the effects of applying knowledge-transforming text (KTT) in EE learning, which is expected to answer four quantitative questions and one quantitative descriptive question.

The quantitative questions are related to the following hypotheses.

1- Does KTT learning pose a significant effect on students' declarative knowledge? H0: Learning with KTT does not pose a significant effect on students' declarative knowledge.

H1: Learning with KTT poses a significant effect on students' declarative knowledge

2- Does KTT learning pose a significant effect on students' procedural knowledge? H0: Learning with KTT does not pose a significant effect on students' procedural knowledge.

H1: KTT learning pose a significant effect on students' procedural knowledge 
3- Does KTT learning pose a significant effect on students' presentation skills?

H0: KTT learning does not pose a significant effect on students' presentation skills.

H1: KTT learning pose a significant effect on students' presentation skills.

4- Quantitaive descriptive question is related to student motivation.

How is students' motivation when engaged in KTT learning?

This study includes the provision of learning material devoted to EE, which is considered appropriate to improve students' declarative and procedural knowledge. The learning material is a supplementary text in the form of basic material texts arranged in a knowledge-transforming fashion or knowledge-transforming text. Then, the provision of learning material in the form of a KTT is investigated for its effects by delving into variables related to (1) declarative knowledge, (2) procedural knowledge, (3) presentation skills, and (4) student motivation towards learning with KTT.

\section{Theoretical Background}

Dehler (1996) mentions knowledge-transforming as an approach associated with the opinion of Bereiter and Scardamalia (1987) which is concerned with intentional learning as "the specific goal of developing independence" aimed at achieving several goals throughout a learner's learning trajectory. Through transforming knowledge, students intentionally and independently learn to construct the meaning of what is learned. Functionally speaking, as Vygotsky (1962) stated, language is an intellectual tool. In addition, Çetin \& Demiral (2012) also state that language is an important tool for medium of self-expression and understanding everything in life. Learning material is closely related to how language is used and activated to serve as a tool for understanding knowledge. Teaching materials as teacher's speech is a component of language use which has a big influence on learning outcomes. Rymes (2008:367) states that learning is an interactive process that makes students not only learn new material, but also learn new ways of speaking and participating. This opinion shows that students learn to communicate and interact through language in classroom including how language is used in text as learning material.

Galbraith (2009) in his research shows that knowledge-telling is a process involving retrieving already-formed "ideas" from an explicit store of knowledge in long-term memory and presumably translating these directly into text. By contrast, knowledgetransforming is the process of goal-directed evaluation and manipulation of ideas or translating them into text. With regard to writing skills, Galbraith (2009) states that the knowledge-transforming model of higher-level reflective thinking is involved in writing. Texts produced by knowledge transformation play a role in helping the students' thinking process to see a concept as a whole and serving as the procedure to perform complete logical steps. This is directly related to descriptive and procedural abilities.

Bereiter \& Scardamalia (1987) show the process of writing model based on the level of expertise and knowledge of the author. This is where knowledge-telling directly conveys information, but does not show complex problem solving activities. By contrast, the transforming knowledge model is done by presenting a context to solve problems germane to various phenomena which require continuous content generation and 
planning. Sevgi (2016) states that the model is in line with the 'content generation process' which is built on Strauss and Corbin's definition of the term 'process' and is described as the idea used in written text._The term 'process' refers to idea used in written text. The planning process that takes place in the rhetorical space refers to the organization and management of these aspects reflected in the text.

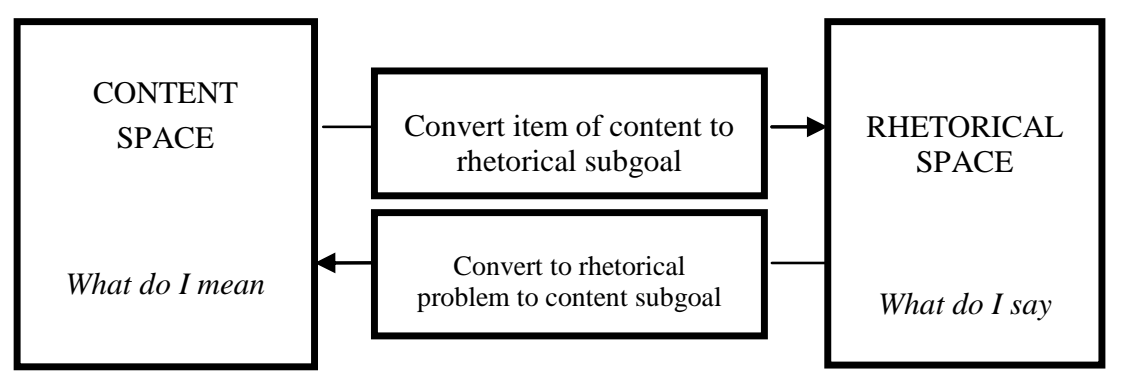

Figure 2

Bereiter \& Scardamalia Knowledge-Transforming Model

The procedure for writing in knowledge-transforming seeks to pay attention to the conative element by realizing what is in the writer's mind towards what will be written by paying attention to the content and rhetorical strategy. Based on the model, knowledge-transforming text in learning will meet the needs of students to (1) understand concepts through points in the text, (2) perform analysis and synthesis of contextual examples, and (3) understand ways and procedures to solve problems in logical work order.

Bereiter \& Scardamalia (2014) explain that there are formidable barriers to instituting knowledge building in education. Some of these are the barriers any intellectually serious approach faces: excessive amounts of material to cover, excessive emphasis on test scores, and so on. On the other hand, there are obstacles driven by the lack of motivation and focusing on efforts to improve students' skills. Therefore, innovation is needed on producing novel materials, alternative tests, and efforts to increase motivation.

The two types of knowledge that underlie knowledge building are declarative and procedural knowledge. The concept of Berge \& Hezewijk (1999) shows the relationship between declarative and procedural knowledge. They say that declarative knowledge is not an alternative knowledge, as is usually the case in memory theory, but rather serves as part of procedural knowledge. Declarative knowledge is related to psychological (cognitive) aspects as the basis of procedural knowledge. Thus, from this opinion it can be said that this knowledge cannot be separated. To understand procedural needs declarative and vice versa. It can be said that in some cases procedural memory is relatively autonomous, compared to declarative memory. Thus, both are very important aspects of knowledge building, as pointed out by Bereiter and Scardamalia (2014).

Declarative knowledge is suggestive or real knowledge, while procedural knowledge is real knowledge that can be seen from working on a series of steps and understanding of 
taking action (Sahdra \& Thagard, 2003). Decalarative and procedural knowledge are complementary in nature. Anderson (1993) states that knowledge starts from declarative, conscious, and control actions. This control paves the way for procedural processes. Declarative knowledge is the basis of knowledge transfer, procedural knowledge plays a significant role in structuring concepts and explaining declarative knowledge (Lawson, et al, 2000). Learning needs to accommodate these two types of knowledge, including text as material learning in text-based learning. Text serves as the main source of information that can be re-read by students and is a reflection of students' knowledge.

\section{Related Studies}

Bank \& Millward (2007) see the relationship between organizational knowledge on teams and teams' performance through differentiating between declarative and procedural knowledge. The results show the effects of procedural knowledge on team performance. Accurate procedural knowledge is positively associated with team performance, and shared procedural knowledge is negatively associated with team performance. This finding is interesting in the context of broader questions pertinent to the organization of knowledge in group work. Thus, to improve group work, accurate procedural knowledge is needed. Simply put, group work without shared procedural knowledge actually has better knowledge performance. This research applies Shared Mental Models (SMMs) to increase declarative knowledge that supports group process and performance. This is in line with Utami, Sa'dijah, Subanji, \& Irawati (2018) who show that the mental model can portray students' thinking process. SMMs in Blank and Millward's (2007) research are used to show declarative and procedural ways of thinking to differentiate team performance in terms of ways of thinking and interacting.

Research on declarative and procedural knowledge shows the relationship between success and knowledge. Yilmaz \& Yalçin (2012) apply the Qualitative Measurement Tool (QMT) obtained from several books and developed by previous researchers. The study looked at understanding Newton's lows of motion in first-year Science students. The results show that students' success rates are higher in procedural-knowledge questions than declarative-knowledge questions, but they are more successful in declarative questioning procedures. In other words, students fail to reflect their higher procedural knowledge for their level of success in declarative knowledge. Since their success rate is higher than their knowledge, it implies that their level of success does not represent their level of knowledge. The study shows that knowledge of procedural action is easier to master than the conceptual knowledge, but is related to the success of procedures to understand the concept.

In general, efforts to increase declarative and procedural knowledge relate to education in all fields, comprising of medicine, language, business, science, environmentalism, and so on. One of them is the study of Abu-Zaed \& Khan (2013) who report an increase in declarative and procedural knowledge through the provision of multiple-choice questions (MCQs). The results of these studies demonstrate that declarative and procedural MCQs can help organize learning process. Declarative learning is the way to promote deep learning. MCQs can integrate scientifically correct (declarative) and 
scientifically-sound (procedural) knowledge in science. This study shows that efforts to stimulate student interaction declaratively and procedurally can be done by giving questions characterized by the declarative and procedural dimensions. Both are important parts of deep learning.

Ashley, Schaap, \& Brujin (2016) report the results of their research through analysis of dialogic interaction and students' writing assignments, descriptive research, and insights on how knowledge-transforming writing contributes to a conceptual understanding of a course for international business students. Pre-, mid- and post-tests revealing conceptual understanding indicate that stimulating knowledge-transforming dialogic writing through class interaction and writing assignments is positively related to the development of students' conceptual understanding. Results suggest that meaning construction, active engagement and knowledge integration are key effects. Educators need to stimulate the self-regulatory processes needed for knowledge-transforming. The results of these studies demonstrate that knowledge-transforming can improve conceptual understanding. The action that needs to be done to optimize the understanding is the management of individual student involvement. The concept in this case is declarative knowledge which can support procedural knowledge.

The characteristics of declarative and procedural knowledge research, based on several studies, include (1) the efforts to increase both knowledge through action (2) the attempts to show the effect and influence of learning on both types of knowledge that broadly shows the level of knowledge in detail, (3) the application of both types of knowledge and the implementation of an approach to increase students' performance. It is necessary to carry out a research on the effect of a learning approach or model on both types of knowledge and further see the resultant effects in detail from both quantitative and qualitative perspectives.

KTT is a process of building knowledge through reading comprehension in which students interact to form knowledge extracted from reading material. In the reading example about "Oxygen Charity" for example, students form descriptive knowledge through understanding what oxygen is, what processes produce oxygen, the environmental conditions with less oxygen, why humans need oxygen, and the need for oxygen charity. The understanding of material is embedded within a dialectic enterprise between content and rhetorical spaces. This is the hallmark of KTT in establishing declarative knowledge. What needs to be considered in reading material is understanding on surface structure and deep structure. Harvey \& Anderson (1996) explain that in declarative knowledge there are two elements of knowledge, namely episodic knowledge containing knowledge of context related to where, when, who and so on; semantic knowledge which contains facts and meanings of words. Thus, it can be assumed that understanding concepts in the text will increase declarative knowledge.

Procedural knowledge is knowledge in understanding working procedures, steps, and how to solve problems according to these steps. The opinion of Berge \&Hazewijk (1999) needs to be underlined, especially the differences between declarative and procedural knowledge. These differences set knowing what apart from knowing how. Declarative knowledge is considered as an alternative kind of knowledge, as is the case 
in theories of memory, but as part of procedural knowledge. This shows that procedural knowledge is strongly supported by declarative knowledge. Similarly, Marzano (2012) points out that we cannot presume that procedural knowledge is more important than declarative knowledge. Declarative knowledge will lead students to take measures to solve problems using their declarative knowledge.

\section{METHOD}

\section{The Design of the Study}

This study employed a of quantitative methods. Quantitative research was applied with control group design in two classes divided into control class and experimental class. The research population included three classes (clusters), and the number of students in each class was 32 students in class A, 32 students in class B, and 33 students in class C. The three classes were tested for homogeneity based on formative values (regular achievement tests) with one way ANOVA test. Furthermore, in the experimental class knowledge-transforming learning was applied, while in the control class the usual learning methodology was applied, namely knowledge-telling text. After 9 learning sessions had been conducted, declarative (DCLR) knowledge tests, procedural (PRCD) knowledge tests, and presentation (PRST) skill tests were conducted, followed by distributing questionnaires to investigate students' motivation towards KTT. The test results of the DCLR, PRCD, and PRST variables of the control and experimental classes were tested with inferential statistics using compare means test analysis with the technique of Mann-Whitney $U$ test and continued with a test of significance value significance compared with 0.05 . The variables were measured quantitative descriptive by using a questionnaire to ask students' opinions on their learning motivation using a KTT with Likert scale.

The DCLR knowledge test in this study contained a test of conceptual knowledge about definitions, meanings of terms, facts, and generalizations. The PRCD knowledge test contained questions about the logical stages of action and how to solve problems based on the right concepts. The PRST test contained presentations of environmental problems around students' lives and their solutions.

The research was carried out from February $4^{\text {th }} 2019$ to February $22^{\text {nd }} 2019$. Learning was carried out for 9 sessions in 3 weeks ( 3 sessions per week). The time needed for each session was 90 minutes.

\section{Participants}

As explained earlier, this study was conducted to investigate the effects of knowledgetransforming text on understanding declarative knowledge, procedural knowledge, the ability to present environmental cases and solutions, and student motivation towards learning using KTT. The number of elementary school students involved in this study was 97 students divided into 3 classes consisting of 32 students in class A, 32 students in class B, and 33 students in class $\mathrm{C}$. These students were at grade 5 of elementary school (they are around 10-11 years old) who received EE material since their first grade. In the experimental class (Class A), students obtained the knowledge- 
transforming text and each session ended with the comprehension question on the contents presented in the readings. These consist of questions related to main points and descriptions of the contents. The reading main points are (1) keywords and (2) main ideas or reading topics. Furthermore, in the description of reading content students answered questions about (1) events in the text or problems, (2) solutions described, and (3) tasks on compiling sentences about the concepts contained in the text.

\section{Instruments}

To meet data requirements, there were 5 instruments employed in this study, namely:

1. Readings related to EE

2. Test on Declarative knowledge

3. Test on Procedural knowledge

4. Test on presentation skills

5. Questionnaire on the implementation of KTT in motivating the mastery of EE material

\section{Procedure and Task}

KTT was applied to the experimental class. There was also a description of the material for the 9 KTT-focused meetings as shown in the table below,

Table 3

Topics of KTT

\begin{tabular}{cl}
\hline Meetings & Text Title \\
\hline 1 & Sedekah Oksigen (Giving Oxygen) \\
2 & Indonesia Pengekspor Asap (Indonesia: Smoke Exporter) \\
3 & Mencangkok Tanaman Mangga dan Jambu (Transplanting Mango and Guava) \\
4 & Hemat Listrik (Save Energy) \\
5 & Tanaman Obat Keluarga (Family Herbal Plants) \\
6 & Tanaman dalam Pot (Plants in Pots) \\
7 & Selamatkan Kehidupan Sosial Kita dengan Gotong Royong (Save our Social Life \\
8 & through "Gotong Royong”/Working Bees) \\
9 & Jus Sehat dan Lezat (Healthy and Delicious Juice) \\
\hline
\end{tabular}

At the first stage, understanding the content of KTT was at work. Students obtained information from the teacher's explanation of the material according to the assigned title for 10 minutes. Afterward, they were given the opportunity to do silent reading, for approximately 30 minutes. As stated above, texts formed with knowledge-transforming strategy involved tasks of highlighting key points, restructuring various sections, and finding the connection between different parts of the material, and using various contexts to support meaningful knowledge. Then, students answered KTT-related comprehension questions and submitted their assignments. Afterwards, they were given score by the teacher. For example, the questions given in the first meeting were related to (1) what are the important points in the reading? (2) what is the topic of the reading? (3) why do we need alms oxygen? (4) How to give oxygen? (5) What are the characteristics that indicate the good air quality around us? 
At the second stage, on the $10^{\text {th }}$ meeting, DCLR knowledge was measured. The teacher distributed DCLR questions to measure students' knowledge of what was understood. The question contained details related to organic and inorganic waste. There were 5 questions covering (1) the definition of organic and inorganic waste (2) the characteristics of organic and inorganic waste, (3) the functions of separating organic and inorganic waste, (4) the sources of organic and inorganic waste, and (5) difficulties in dealing with organic waste and inorganic. Then, the researchers recorded the students' scores.

At the third stage, still on the $10^{\text {th }}$ meeting, PRCD was measured by distributing questions about how to do something in accordance with declarative concept and knowledge. In this test, students were required to explain how to make organic fertilizer from dried leaves that fell to the ground. Then, the researchers recorded students' scores.

At the fourth stage, a performance test was conducted, in the form of a PRST test. The test was carried out on the next day after DCLR and PRCD. The test was in the form of a presentation about the problem of waste around the students' environment and how to overcome it. On this test, each student was given the opportunity to deliver a presentation for 10 minutes at most. Then, the researchers recorded the students' scores.

In the fifth stage, the questionnaire was given. The questionnaire aimed to garner descriptive evidence on students' motivation towards the implementation of KTT.

Questionnaire in the form of test questions, coupled with Likert scale ranging from 1 to 5 , was operative. The questionnaire included 5 questions.

In this study, quantitative analysis was conducted by (1) normality test by KolmogorovSmirnov non parametric one-sample statistical test, (2) different test tests with nonparametric statistics Mann Whitney U-Test, and (3) significance test by comparison against a value of 0.05 . Qualitative results analysis is done by calculating the percentage of students' motivation towards KTT and describing the results to highlight essential meaning.

\section{FINDINGS AND DISCUSSION}

As stated earlier, the novelty in this study is to know the effect of learning through text that is read by students toward their declarative knowledge, procedural knowledge, and presentation skills. Declarative and procedural knowledge of students is indicated by the performance in DCLR knowledge test with knowledge question maps on definitions, characteristics, concepts, and functions; test on PRCD knowledge involves map of knowledge of solutions and steps to solve problems. Next, a PRST test is performed. On the PRST test, students bring their work into a demonstration.

Quantitative Analysis Effect of KTT on DCLR, PRCD Knowledge, and PRST Skill

The population in this study were class A involving 32 students, class B involving 32 students, and class C involving 33 students. In total, 97 students were involved. Then the 
homogeneity test was carried out based on the results of the previous formative test with one way ANOVA inferential statistical test with the following results.

Table 4

Test of Homogeneity of Variances

\begin{tabular}{llll}
\hline Levene Statistic & df1 & df2 & Sig. \\
\hline 1,274 & 2 & 94 &, 284 \\
\hline
\end{tabular}

Based on the table above, sig $0.284>0.05$ indicates that all classes belonging to the population are homogeneous. Furthermore, from the three classes, class A is selected as the experimental class, and class B is the control class. Taking these two classes as samples from the population is done by cluster random sampling.

Table 5

Normality Test: One-Sample Kolmogorov-Smirnov Test

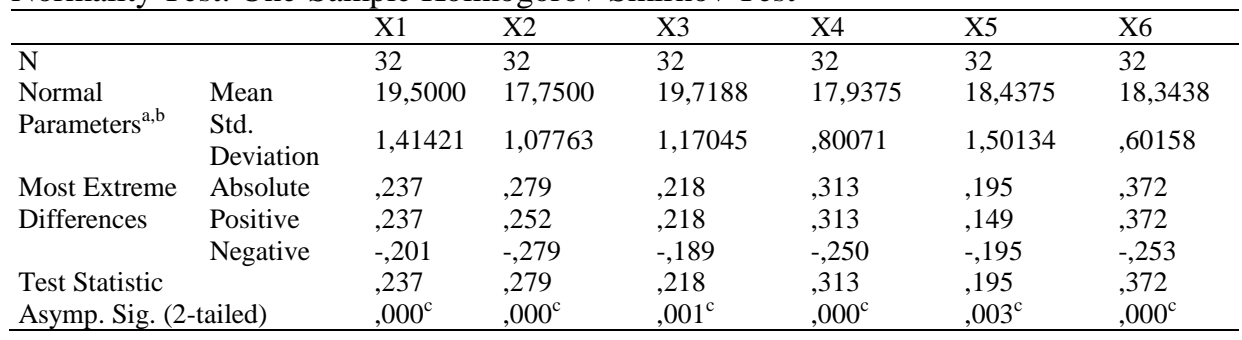

Before the effect test of KTT learning on declarative knowledge, procedural knowledge, and presentation skills, normality tests were carried out with the non-parametric statistical test using one-sample Kolmogorov-Smirnov test, generating the following results.

The table 4 shows $\mathrm{X} 1$ as the declarative knowledge test results of the experimental class, $\mathrm{X} 2$ as test results of declarative knowledge test of the control class, X3 as test results of procedural knowledge test of the experimental class, $\mathrm{X} 4$ as test results of procedural knowledge of control class, $\mathrm{X} 5$ as the test results of experimental class in presentation test, and X6 as the test results of control class in presentation test. Based on the table above, it can be interpreted that the results of a declarative knowledge, procedural knowledge, and presentation skills test are unnormally distributed (Asymp. Sig. (2tailed) $0,000<0,05)$. Therefore, this research has applied Mann-Whitney U test nonparametric statistics to compares the means between unrelated groups on some continous.

\section{The effect of KTT on declarative knowledge}

The results of tests on declarative knowledge by Mann-Whitney $U$ test nonparametric statistic in the experimental class (1) and the control class (2) can be investigated in following table. 
Table 6

Effect Test of KTT on DCLR Knowledge

\begin{tabular}{|c|c|c|c|c|}
\hline \multirow[t]{2}{*}{ Ranks } & & & & \\
\hline & $\overline{\text { Class }}$ & $\mathrm{N}$ & Mean Rank & Sum of Ranks \\
\hline \multirow[t]{3}{*}{$\overline{\text { DCLR }}$} & 1,00 & 32 & 43,48 & 1391,50 \\
\hline & 2,00 & 32 & 21,52 & 688,50 \\
\hline & Total & 64 & & \\
\hline \multicolumn{5}{|c|}{ Test Statistics ${ }^{\mathrm{a}}$} \\
\hline & & DCLR & & \\
\hline \multicolumn{2}{|c|}{ Mann-Whitney U } & 160,500 & & \\
\hline \multicolumn{2}{|c|}{ Wilcoxon W } & 688,500 & & \\
\hline \multicolumn{2}{|l|}{$\mathrm{Z}$} & $-4,872$ & & \\
\hline \multicolumn{2}{|c|}{ Asymp. Sig. (2-tailed) } & ,000 & & \\
\hline
\end{tabular}

These results indicate that the significance value is $\alpha / 2$. The significance is $0.000<0.05$, which means that $\mathrm{H} 0$ is rejected and $\mathrm{H} 1$ is accepted. In other words, KTT learning poses significant effect on students' declarative knowledge in understanding EE material.

Several points about these results need to be elaborated. As explained earlier, EE in Indonesia is carried out by reading and answering questions as in figure 1 . In one chapter, students read 3 texts. On the other hand, the text was presented in a knowledgetelling manner, with inadequate rhetorical aspects. Galbraith (2014) shows that there are two features in writing. First, it reflected the facts related to ideas represented, not only as a reflection of the author's knowledge (content space), but also in terms of their rhetorical functions in the text (rhetoric space). Second, writing is not just a matter of adapting content to a rhetorical context, but rather serves as an emerging process in which content is formulated as developing text, using context to support rhetorical aspects. Both are fulfilled in knowledge-transforming writings. Bereiter and Scardamalia (1987) contend that a KTT characterized by the use of such techniques as highlighting key points, restructuring various sections, finding connection between different parts of material, and using various contexts to support meaningful knowledge.

Content space and rhetorical space make it easier for students to understand concepts and various real problems and solutions. The key lies in developing content formulation. Thus, although it retains the knowledge-telling model as a content comprehension retrieved from memory, this is embedded in a dialectic space between content and rhetorical spaces (Galbraith, 2014). That being said, characteristics of objects, functions, and concepts of objects that are part of declarative knowledge are embedded within a dialectic space between content and rhetorical spaces. Thus, what Glassman (2001) says is that language serves as an intellectual tool as conceptualized by Vigotsky (1962) through language knowledge management, making content easily understood. Through rhetorical space, knowledge can be made more meaningful. This view supports the results of KTT which pose an effect on declarative knowledge. Similarly, research by Ashley, Schaap, \& Brujin (2016) shows the application of knowledge- transforming actions. The results demonstrate that stimulating knowledge-transforming writing is positively related to the development of students' conceptual understanding. This shows 
that there are conceptual features in KTT both in the text and in their performance that can increase declarative knowledge.

\section{Effect of KTT on procedural knowledge}

The results of tests on procedural knowledge by Mann-Whitney U test nonparametric statistic in the experimental class (1) and the control class (2) can be investigated in following table.

Table 7

Effect Test of KTT on PRCD Knowledge

\begin{tabular}{lllll}
\hline Ranks & & & \\
\hline & Group & $\mathrm{N}$ & Mean Rank & Sum of Ranks \\
\hline PRCD & 1,00 & 32 & 44,94 & 1438,00 \\
& 2,00 & 32 & 20,06 & 642,00 \\
& Total & 64 & & \\
\hline \multicolumn{4}{c}{ PSDR } \\
\hline Mann-Whitney U & 114,000 & \\
Wilcoxon W & 642,000 & \\
Z & $-5,508$ & \\
Asymp. Sig. (2-tailed) &, 000 & \\
\hline
\end{tabular}

These results indicate that the significance value is $\alpha / 2$, a significance value of 0.0000 $<0.05$, which means that the hypothesis H0 is rejected and H1 is accepted. In other words, learning with KTT has a significant effect on students' procedural knowledge in understanding EE material.

KTT helps students to gradually understand declarative and procedural knowledge. Procedural knowledge, for example, is understanding how oxygen is produced and how to solve the problem of reduced oxygen, how to give oxygen, and how to plant trees.

KTT can provide corrections to what was done. In this research, KTT presents the problems and solutions to the functions of the actions taken. For example, in the step of planting trees there are recommendations about spacing. KTT explains why and how these actions should be carried out as material for correction on things that should not be done. By understanding these steps in detail, students can understand how to do things. Wang's research (2016) also indicates similar finding. The applied Metalinguistic Corrective Feedback (MFC) has been proven to increase declarative and procedural knowledge. Learners' declarative knowledge on both structures has also improved, but not as drastically as has their procedural knowledge. MCF plays a positive role in bridging the gap between declarative knowledge and procedural knowledge (Wang, 2016). MCF facilitates the proceduralization of declarative knowledge, i.e. procedural knowledge has increased significantly through MCF actions which are hierarchically carried out with detailed word correction and structure. By understanding the details and causality relationships between problems and solutions, learning procedures can increase procedural knowledge.

The research findings relate to KTT in terms of the element of correction. The corrective actions contained in the MFC and KTT have major effect on procedural 
knowledge. In addition, procedural knowledge denotes proceduralization of declarative knowledge. This research also explains how students understand procedural knowledge based on declarative knowledge. This is the case when students improve their procedural knowledge based on the understanding that humans need oxygen, that oxygen is obtained from plants, and that oxygen deprivation has taken place. Students therefore understand why oxygen is needed. With the knowledge that plants take nutrients from the soil, students understand the meaning of spacing. In the end, students comprehend procedural knowledge about how to plant trees. Thus, procedural knowledge is supported by declarative knowledge. In other words, the statement of Berge \& Hazewijk (1999), stating that declarative is part of procedural, has been proven.

\section{The effects of KTT on presentation skills on environmental problems and solutions}

The results of tests on presentation skills ability by Mann-Whitney $U$ test nonparametric statistic in the experimental class (1) and the control class (2) can be investigated following table.

Table 8

Effect Test of KTT on PRST Skill

\begin{tabular}{|c|c|c|c|c|}
\hline \multirow[t]{2}{*}{ Ranks } & & & & \\
\hline & Class & $\mathrm{N}$ & Mean Rank & Sum of Ranks \\
\hline \multirow[t]{3}{*}{ PRTS } & 1,00 & 32 & 34,52 & 1104,50 \\
\hline & 2,00 & 32 & 30,48 & 975,50 \\
\hline & Total & 64 & & \\
\hline \multicolumn{5}{|c|}{ Test Statistics $^{\mathrm{a}}$} \\
\hline \multicolumn{5}{|c|}{ DCLR } \\
\hline \multicolumn{2}{|c|}{ Mann-Whitney U } & 447,500 & & \\
\hline \multicolumn{2}{|c|}{ Wilcoxon W } & 975,500 & & \\
\hline \multicolumn{2}{|l|}{$\mathrm{Z}$} &,- 919 & & \\
\hline \multicolumn{2}{|c|}{ Asymp. Sig. (2-tailed) } & ,358 & & \\
\hline
\end{tabular}

These results indicate that the significance value is $\alpha / 2$, which is $0,358 / 2=0,179$. Thus, the significance value is $0.179>0.05$, which means that the hypothesis $\mathrm{H} 0$ is accepted and $\mathrm{H} 1$ is rejected. In other words, the implementation of KTT does not have a significant effect on the students' presentation skills on issues concerned with the environmental problems and their solutions.

Presentation is a combination of knowledge, skills to do things, and the ability to convey ideas in spoken language. In KTT, students get content-based information packaged in rhetorical strategies to make it easier for students to understand the material. In presentations, students must express information and employ rhetorical strategies correctly by preparing themselves before presentation. This seems to have a considerable effect on their presentation skills. Although in general, they master the concepts and procedures, but there are some assessment indicators that have not been met by students, especially on the quality points of action to be taken. For example, when students explain how to make natural fertilizers, students do not explain the target of incorporating materials, managing, and use tools. In other words, student 
presentations are not accurate. This shows the students' weak control over conative functions. Conative function is language function related to emphasizing the understanding of listeners (Bühler, 2011). These conative functions have not been well taken into account by students as part of their presentation. In presentations, students should not only apply referential functions, but also conative functions.

Bank \& Millward's (2007) research shows the complexity of presentation problems. The SMMs or Shared Mental Models model is a shared declarative knowledge between teams related to team performance. Conversely, shared procedural knowledge is negatively related to team performance. Accurate procedural knowledge was positively related to team performance. Therefore, procedural information sharing carried out by the team does not affect the group's performance. Students need to obtain procedural knowledge because the distribution of procedural information in the groups does not indicate positive contribution.

What needs to be considered from these studies is accurate procedural knowledge in presentation or team performance. Presentation requires not only declarative and procedural knowledge, but also the skills to convey ideas verbally as part of productive language skills. This is part of accurate procedural knowledge. Without accuracy of the procedural knowledge, presentation will be flawed. The problem of describing the quality of actions expected in each step described by students demonstrates the lack of accurate procedural knowledge. This can be assumed to be the cause of the insignificant effect of KTT on procedural knowledge.

\section{Quantitative Analysis of Students' Motivation towards Learning with KTT}

Based on the results of the student motivation questionnaire about learning with KTT, the following results are obtained.

Table 9

Percentage of Learning Motivation Questionnaire toward KTT

\begin{tabular}{|c|c|c|c|c|c|c|c|c|c|c|}
\hline \multirow{3}{*}{ Statements } & \multicolumn{10}{|c|}{ Attitude } \\
\hline & \multicolumn{2}{|l|}{1} & \multicolumn{2}{|l|}{2} & \multicolumn{2}{|l|}{3} & \multicolumn{2}{|l|}{4} & \multicolumn{2}{|l|}{5} \\
\hline & $f$ & $\%$ & $f$ & $\%$ & $f$ & $\%$ & $f$ & $\%$ & $f$ & $\%$ \\
\hline KTT is fun & 0 & 0 & 4 & 12,5 & 3 & 9,37 & 16 & 50 & 9 & 28,13 \\
\hline $\begin{array}{l}\text { I am interested in learning activity } \\
\text { using KTT }\end{array}$ & 0 & 0 & 7 & 21,9 & 2 & 6,25 & 18 & 56,25 & 5 & 15,6 \\
\hline $\begin{array}{l}\text { KTT helps me to understand material } \\
\text { better }\end{array}$ & 0 & 0 & 8 & 25 & 0 & 0 & 21 & 65,62 & 3 & 9,38 \\
\hline $\begin{array}{l}\text { KTT is more comprehensible than } \\
\text { texts in school textbooks }\end{array}$ & 0 & 0 & 2 & 6,25 & 0 & 0 & 21 & 65,62 & 9 & 28,13 \\
\hline I want to learn with KTT & 0 & 0 & 5 & 15,62 & 0 & 0 & 23 & 78,87 & 5 & 12,51 \\
\hline
\end{tabular}

\footnotetext{
Description

1: strongly disagree

2: disagree

3: neutral

4: agree

5: strongly agree
} 
From the questionnaire results, it is known that students want to learn using KTT, as evinced by 23 students reporting this attitude or $78.87 \%$ of total sample. On the other hand, this is corroborated by the fact that $65.62 \%$ of the students' report that KTT makes it easier for them to understand the material and $65.62 \%$ state that they are encouraged to explain problem and solution in detail. This shows their positive attitude toward KTT. The other findings from questionnaire confirm support for these two indicators. Thus, it can be stated that in general students express positive attitudes in the form of desires, interests, and objective judgments voicing the idea that KTT presents problems and solutions in detail and facilitates understanding. These indicate that they are motivated to learn with KTT strategy.

\section{CONCLUSION}

Based on the findings and discussion above, a number of conclusions regarding the effects of KTT on declarative, procedural, and presentation knowledge, as well as student motivation towards learning using KTT are drawn.

Answering the first question, the students' ability in the experimental class, who study knowledge-transforming text material to achieve declarative knowledge, are found to perform better than those in the control class who learn with knowledge-telling text. The implementation of Knowledge-transforming text has a significant effect on students' declarative knowledge about EE material with a significance value of $0.000<0.05$. This is supported by the condition of KTT-driven learning. KTT contains two features, namely (1) content space and (2) rhetoric space. Content space and rhetoric space are portrayed in developing text assisted by the supporting real context. Both of these features are considered the formula for KTT, particularly related to the use of such techniques as highlighting key points, restructuring various sections, finding connection between different parts of material, and using various contexts to support meaningful knowledge. These techniques support the development of declarative knowledge. The research findings contend that the features of KTT improve students' declarative understanding. It can also imply that KTT can increase declarative knowledge.

Answering the second question, the students in the experimental class who study the transforming text knowledge material to achieve procedural knowledge perform better than those in the control class who learn with knowledge-telling text. The application of Knowledge-transforming text poses a significant effect on students' procedural knowledge about EE material, as evinced by a significance value of $0,000<0.05$. This is acknowledged by the context of KTT which provides a description of logical steps. Students understand how to perform an action, why it should be done in certain way, and what factors support and hinder the success of the action. Corrective measures on incorrect performance or product have to be avoided at all costs. Thus, it can be assumed that discourse production through KTT can increase students' procedural knowledge. Moreover, it can be implied that KTT possesses the indicators contributing to improved procedural knowledge.

Answering the third question, the experimental class learning with KTT has resulted in slightly better presentation skills than has the control class learning. Although the scores 
of student presentation skills in the experimental class are better than their peers, this does not bring about a significant effect as corroborated by significance value of $0.372>0.05$. This relates to accurate procedural knowledge in presentations. Based on the research findings, it can be stated that accurate procedural knowledge denotes the actualization of declarative knowledge, procedural knowledge, and presentation skills in expressing ideas related to problems and their solutions in logical sequences as well as corrective statements on how they work. In addition, this has to be supported by the statement describing the quality of each step or action taken. This shows the complexity of the presentation made by the students. At this point, it can be assumed that the insignificance of KTT aforementioned is influenced by students' lack of accurate procedural knowledge.

Answering the fourth question, students are basically motivated to engage in KTT learning. The questionnaire results show that most students express their desires, interests, and objective assessments expressed in the judgments which point out that KTT presents problems and solutions in detail and also facilitates understanding. These indicate that they are motivated to engage in KTT learning. This has implications for EE learning in Indonesia to use KTT as a reference for EE learning that requires understanding on real concepts and practices in preserving the environment.

\section{LIMITATIONS AND SUGGESTIONS FOR FURTHER RESEARCH}

There are limitations in this study. First, this study is applied to small-scale populations with 3 clusters due to the limited number of parallel classes in Indonesian schools. This can be a consideration to expand future research in terms of population and research actions as well as data collection in a relatively longer timespan. To see the impact of learning in detail, classroom observation is needed. Therefore, in further research it is necessary to apply qualitative methods such as observation and group discussion to get precise findings.

Second, KTT learning practices are oriented to environmental education material that involves textual learning material. Texts in environmental education are easier to be expanded with respect to its concept and context. Thus, it is easier to organize content space and rhetorical space in producing KTT. It is difficult to apply KTT to material that requires practical actions whose concepts and theories require a lot of declarative or procedural knowledge. Implementing KTT on these materials requires more in-depth thinking. Therefore, the results in this study imply the need for broader generalization in terms of material choices. In further research, future researchers need to ponder material characteristics or subjects who will receive KTT learning.

Thirdly, the students' initial ability in reading is a variable that can be assumed to influence their understanding of KTT. In this study, the students' reading comprehension is not taken into account. Homogeneity is only taken from formative tests. Therefore, in further research it is necessary to put the students' reading comprehension under investigation to investigate their ability to understand KTT. 


\section{REFERENCES}

Abu-Zaid, A. \& Khan, T. A. (2013). Assessing declarative and procedural knowledge using multiple-choice. Medical Education Online, 22(18), 21132. doi: 10.3402/meo.v18i0.21132.

Anderson, J. R. (1993). Rules of the mind. Hillsdale, NJ: Lawrence Erlbaum Associates.

Ashley, S., Schaap, H., \& Brujin, E. D. (2016). Stimulating knowledge-transforming writing to foster conceptual understanding in international business student. 15th EARLI SIG Coference on Writing (pp. 1-10). Liverpool, UK: Utrecht University.

Banks, A. P., \& Millward, L. J. (2007). Differentiating knowledge in teams: The effect of shared declarative and procedural knowledge on team performance. Group DynamicTheory Research and Practice 11(2), 95-106.

Berge, T. \& Hezewijk, R. (1999). Procedural and declarative knowledge: An evolutionary perspective. Theory \& Psychology, 606-624.

Baumard, P. (1999). From tacit to explicit, the conjectural pattern of knowing. In P. Baumard (Ed.), Tacit knowledge in organization (pp. 52-77). London: Sage Publication.

Bereiter, C., \& Scardamalia, M. (1987). The psychology of written composition. Hillsdale, NJ: Lawrence Erlbaum Associates.

Bereiter, C., \& Scardamalia, M. (2014). Knowledge building and knowledge creation: One concept, two hills to climb. In H. J. S. C. Tan (Eds), Knowledge creation in education (p. 35-52). Singapore: Springer.

Bühler, K. 2011. Theory of language. Amsterdam/Philadelphia: John Benjamins.

Çetin, A. \& Demiral, H. (2012). Evaluation of language and literature skill of secondary school students in Turkey according to international baccalaureate diploma program criteria. International Journal of Instruction, 5(2), 153-172.

Dehler, G. E. (1996). Management education as intentional learning: A knowledgetransforming approach to written composition. Journal of Management Education, 20(2), 221-235. doi: 10.1177/105256299602000205.

Galbraith, D. (2009). Cognitive models of writing. German as Foreign Lan., 2-3, 7-22.

Glassman, M. (2001). Dewey and Vygotsky: Society, experience, and inquiry in educational practice. Edu. Researcher, 30(4), 3-14. doi: 10.3102/0013189X030004003.

Harvey, L., \& Anderson, J. (1996). Transfer of declarative knowledge in complex information-processing domains. Human-Computer Interaction, 11, 69-96.

Jiamu, C. (2001). The great irnportance of the distinction between declarative and procedural knowledge. Análise Psicológica, 19(4), 559-566. doi: 10.14417/ap.362. 
Kemendikbud. (2013). Modul implementasi kurikulum 2013 (2013 Curriculum Implementation Module). Jakarta: Kementrian Pendidikan dan Kebudayaan Republik Indonesia.

Kul, Ü., Çelik, S., \& Aksu, Z. (2018). The impact of educational material use on mathematics achievement: A meta-analysis. International Journal of Instruction, 11(4), 303-324.

Lawson, A. E., Alkhoury, S., Benford, R., Clark, B. R., \& Falconer, K.A. (2000). What kinds of scientific concepts exist? Concept construction and intellectual development in college biology. Journal of Research in Science Teaching, 37(9), 996-1018. doi: 10.1002/1098-2736(200011)37:9<996::AID-TEA8>3.0.CO;2-J.

Marzano, R. J., \& Pickering, D. J. (2012). Dimension of learning. USA: ASCD

Renkema J. (2004). Introduction to discourse studies. Amsterdam and Philadelphia: John Benjamins.

Rymes, B. 2008. Classroom discourse: A tool for critical reflection. Cresskill, NJ: Hampton Press

Sahdra, B., \& Thagard, P. (2003). Procedural knowledge in molecular biology. Philosophical Psychology. 16(4), 477-498.

Suwandi, S. (2013). Pembelajaran bahasa dan sastra Indonesia dalam lurikulum 2013: Beberapa catatan terhadap konsep (Indonesian Language and Literature Learning in Curriculum 2013: Some Notes on Concepts). Seminar Nasional Jurusan Pendidikan Bahasa dan Sastra Indonesia (p.7-15). Yogyakarta, Indonesia: FBS, Universitas Negeri Yogyakarta.

Sevgi, E. (2016). A comparison of the cognitive processes involved in L2 learners' writing process when they are composing in English and in their L1. International Conference on Teaching and Learning English as an Additional Language, (p. 347353). Antalya, Turkey: Elsevier.

Utami, A. D., Sa'dijah, C., Subanji, \& Irawati, S. (2019). Students' pre-initial mental model: the case of Indonesian first-year of college student. International Journal of Instruction, 12(1), 1173-1188. doi: 10.29333/iji.2019.12175a.

Vygotsky, L. S. (1962). Language and thought. Ontario: Massachusetts Institute of Technology.

Wang, Q. (2016). bridging the gap between declarative knowledge and procedural knowledge through metalinguistic corrective feedback. Boston: Boston University Theses \& Dissertations.

Yilmaz, İ., \& Yalçin, N. (2012). The relationship of procedural and declarative knowledge of science teacher candidates in newton's laws of motion to understanding. American International Journal of Contemporary Research, 50-55. 